\title{
Paul's biblical patterns of church planting: An effective method to achieve the Great Commission
}

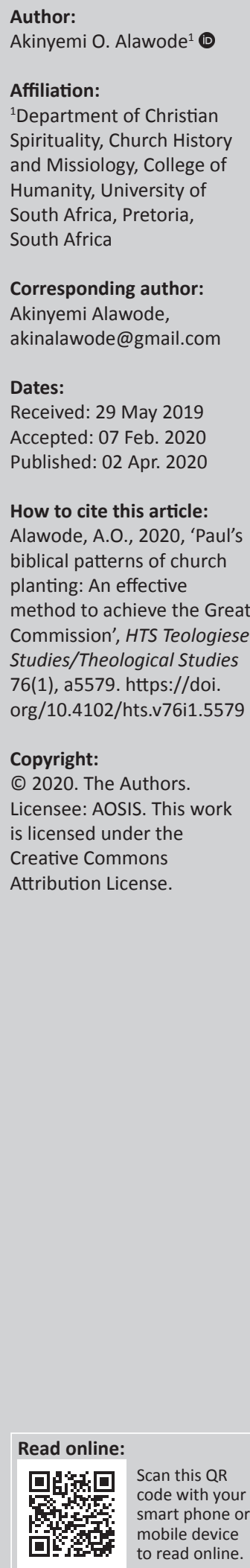

The mandate to make disciples of all nations remains the churches' task before the return of Christ. Church planting is the best way to achieve this mandate. Hence, the biblical patterns as exemplified by Paul the apostle and their relevance to achieving the Great Commission have been the focus of this work. Paul shows through his patterns of church planting the relevance and influence of the Holy Spirit in establishing new centres of worship. Thus, contemporary church planters must seek to emulate Paul in obedience to the Great Commission through church planting, which remains the most effective evangelistic methodology.

Keywords: church planting; biblical patterns; Great Commission; disciple making; God's mandate; contemporary church planters; effective evangelistic methodology.

\section{Introduction}

The love of God for humanity remains strong. Hence, the mind of God that no one should perish is still as strong as it was when Christ said so (cf. Mt 18:11-14). The mission of Jesus Christ was to save and bring restoration to humanity from its state of sin and oppression to glory and dominion. Jesus paid the price totally when he died on the cross. However, Christians need to tell humanity about this good news of the salvation that Christ Jesus offers and the need to commit to a relationship with him, to enjoy the overflow of his grace and love.

Thus, Jesus' commission to the disciples was to make disciples of all nations (cf. Mt 28:19). The disciples became outstanding and experienced the great expansion of the gospel by the power of the Holy Spirit after the Pentecost (cf. Ac 2:41, 47; 4:4). The inability of men to stop the move of the Spirit through them created many enemies among whom was Saul of Tarsus (Paul), who later through an encounter with Christ became his follower and an apostle (cf. Ac 9:1-6). Paul's commitment to the cause of Christ made him an outstanding apostle of Jesus with generational accomplishments. It is therefore in the interest of this article to examine the patterns of Church planting Paul utilised or engaged in the accomplishment of the Great Commission. Hence, objectively, an overview of church planting will be examined, an examination of Paul's patterns versus other patterns and the relevance of Paul's patterns to achieving the Great Commission.

\section{Overview of church planting}

Viewing church planting from an eternal perspective enables one to appreciate the relevance and necessity of this task, and this is possible in the sense that the Bible compels believers to see the world from God's viewpoint, which flows into eternity (Becker, Carpenter \& William 2003:Sec 1-1). God designed church planting to expand his kingdom. Thus, the eternal perspective of church planting rests in the fact that it is a means of rescuing lost souls for Christ eternally. Thus, a survey of the biblical concept of church planting will be appraised.

\section{Biblical concept of church planting}

Peter Wagner in Church Planting for a Greater Harvest asserted that 'the single most effective evangelistic methodology under heaven is planting new churches' (1990:11). He underlined that when people decide to follow Jesus and their action is not followed up by bringing them into a local congregation, such decision may merely become a gesture. Hence, church planting becomes the means to nurture the results of evangelism. A failure to make an explicit nexus between evangelism and the local congregation is a strategic blunder (Wagner 1990:12).

Rolland Allen affirmed that the expansion of the church involves not only the multiplication of Christians but also the multiplication of churches (1962:7). 
According to Stuart Murray (1998):

The practice of church planting may encourage the conclusion that reproduction is as fundamental a feature of the church as it is of biological organisms. A healthy church does not just develop internally and expand in size and social impact, but naturally expresses its life in new forms and structures. (p. 57)

It implies that the growth and development of a church must not only be internal but also equally external through reproduction via new forms and structures. The image of a healthy church is illustrated through human development, which begins with birth, growth and development to the point of maturity and then reproduction after their kind. Thus, a healthy church must be able to reproduce after its kind.

Elli and Mitchell (1992:73) hold that 'if a church exists which never thinks about reproducing itself ... never expects or anticipates that this is the natural business of growing up, then it is sterile'. It thus becomes evident that church planting is an activity that every church should engage in for growth, multiplication and expansion in pursuance of the Great Commission mandate to make disciples of all nations.

Payne (2016) in the same light stated:

Biblical church planting followed the way modelled by Jesus and imitated by the Apostolic Church for global disciple-making. It is a methodology and strategy for bringing in the harvest, raising leaders from the harvest and sending leaders to work in the harvest fields. It is evangelism resulting in gathering people in a church. Under the leadership and work of the Holy Spirit, biblical church planting seeks to translate the gospel and the irreducible ecclesiological minimum into any given social context, with the expectation that new communities of believers, in turn, will continue the process in their contexts and throughout the world. (p. 2)

The above assertion expands the notion that the Great Commission and church planting operate in the form of a cycle, in which new believers gathered, and disciples trained to be leaders for replication and multiplication in their context. It is a process that should not end until we reach the world for Christ. He further holds that the apostolic church had been given the mandate to bear witness to Christ and his resurrection by making disciples of all nations. However, he holds that the best context for making disciples is the local community of disciples, which is the church. Thus, church planting enables the making and maturing of disciples (Glasser \& McGavran 1983:26).

Stuart Murray noted, 'Church planting reminds missiologist that the church plays a pivotal role in mission ... church planting reminds ecclesiologists that mission is the primary task of the church' (1998:57). Payne (2016:2) also noted that a close look at the Great Commission reveals that it was within a church planting context. Of particular note to church planters are Jesus' patterns emphasising the importance of working with receptive peoples and releasing new believers to proclaim the gospel. Payne further holds that Jesus asked the disciples to focus on those who were willing to listen to the gospel (cf. Mt 10:11-16; Lk 10:5-16). Jesus also knew that new believers could spread the good news he brings (cf. Mk 5:19-20). He thus concludes on the note that it is wisdom for church planters to challenge new believers to start witnessing about God's grace as soon as they accept Christ Jesus as their Lord and personal Saviour. In view of this, the author hereby considers Pail's church planting patterns.

\section{Paul's church-planting patterns}

The focus here is to illustrate and outline patterns of church planting as used by Paul in contrast to some other contemporary patterns.

Firstly, Paul focussed on preaching to responsive people. This attitude adopted by Paul was given to the disciples by Christ in Matthew 10:11-16 and Luke 10:5-16. Jesus emphasised to the disciples to go to people who were receptive to their message, but should not overlook the non-receptive; moreover, they were to focus on those ready to hear (Payne 2016:3). Morgan (2013) supported this assertion by emphasising that Paul always felt that it would be better to move to a more sensitive area if the message persecuted by one group of people. Thus, when Paul and his team arrived in Philippi, they went to the riverside and spoke to some women who would listen to them.

Through this strategy, Lydia and her household converted to the Lord (cf. Ac 16:12-15). According to Paul's experience, the devout gentiles were responsive to the gospel. The Bereans were also more responsive than the Thessalonians as they preached the gospel (cf. Ac 17:1-14).

Secondly, Paul and his team established churches in strategic cities and towns of the Roman Empire. From the account in the Book of Acts, it is revealed that his strategy to make disciples began through the preaching of the gospel and the establishment of churches in the cities (Carlos Autida 2012:2). Morgan (2013) also emphasised that Paul focussed his attention on reaching men in large cities. The understanding of this strategy reveals that Paul chose to use the cities as the centre through which to spread the gospel to other provinces because many people from the provinces frequently move to the cities (Morgan 2013) (cf. Ac 13).

Thirdly, Paul emphasised the strategy of house churches, which was very useful in reaching out to families. Homes were primary instruments for Christian life and formation. In Paul's approach, the converts ranged from individuals to their entire families, which may include slaves, friends and even neighbours (W. Arn \& C. Arn 1982:37). Some of such illustrations are Lydia and her household (cf. Ac 16:14-15), the jailor and his household (cf. Ac 16:32-34) and Crispus and Stephanas (Ac 18:8). This strategy is possibly effective in areas or cities and nations where the gospel was not accepted. Jesus used this same strategy as he preached in the houses he entered and to those who came to hear him (Cf. Lk 5:29-32; 19:1-10). 
Fourthly, Paul contextualised the message of the gospel through the methods he used to suit the audience to which he was preaching. The method could always change, but the message remained the same (Ikechukwu Ugo 2012). Paul's approach to the Jews and the pagans of Lystra was different (cf. Ac 14). However, in all the approaches used by Paul in the establishment of kingdom communities, he continually succumbed to the directive of the Holy Spirit. Thus, he recorded significant success in his mission. Gschwend (2017) referred to the Holy Spirit as an expert church planter, and as Holy Spirit uniquely planted every church, every church planter must therefore develop an ever-increasing intimate relationship with the Holy Spirit, being the only one, who can help in contemporary church-planting efforts. The author hereby considers the contemporary church-planting models.

\section{Contemporary church-planting models}

While discussing church-planting approaches, Cheyney, Putman and Sander (2003:57) came up with the following six models that are employed in North America and have been found to be useful. These can also be studied, modified and adapted to suit other regions:

1. Programme-based church planting is the planting of a church that will minister to people and grow through a variety of church programmes. These programmes will consist of some combination of evangelism; discipleship; youth, children's, men's, women's and music ministries; missions; and social ministries.

2. Purpose-based church planting is the planting of a church that will focus on the five purposes of a church, namely, outreach, worship, fellowship, discipleship and service.

3. Seeker-based church planting is the planting of churches that intentionally target specific seeker populations and position themselves to respond to their needs. Everything performed in the church service is focussed on connecting with the spiritual seeker.

4. Ministry-based church planting is the planting of a church that will go into the community, impact people's lives and draw them towards the gospel. Meeting specific social and spiritual needs of the audience is emphasised.

5. Relation-based church planting is relatively new and attempts to solve the riddle of reaching and assembling people who reject institutional forms of church. Relation-based churches are networks of single-cell churches or house churches. These churches are fluid and spread along relational lines through natural social networks.

6. Affinity-based church planting involves the starting of a church among a specific people group or population segment. These groups of people are distinguished by ethnicity, language, world view, socio-economic factors and lifestyle preferences. With careful reflection on contemporary church-planting models, the author now considers the essence of church planting.

\section{Essence of church planting}

Church planting is about pushing the frontier of the kingdom of God beyond its present location and in line with the Great Commission, and among many things, it is meant to achieve the following:

1. Assembling the saved souls: This assemblage is necessary to form the new believers into a Christian community where it will be possible for them to begin to relate as brothers and sisters in Christ. Living this way creates a unique bond that will encourage spiritual growth.

2. Caring for one another: The life of brotherliness by coming together allows helping those who are in need either spiritually or materially. Acts 4 says:

Neither was there any among them that lacked: for as many as were possessors of lands or houses sold them and brought the prices of the things that were sold and laid them down at the apostles' feet: and distribution was made unto every man according as he had need. (vv. 34-35)

3. Apostles' teaching and discipleship: Forming into a church, those who accepted Christ newly makes it easier for the apostles' teaching and discipleship to be performed with everyone at once without creating much stress for those who will be involved in teaching. Acts 2:

Then they that gladly received his word were baptized: and the same day there were added unto them about three thousand souls. Moreover, they continued steadfastly in the apostles' doctrine and fellowship, and in the breaking of bread, and in prayers. (vv. 41-42)

Through the apostles' teaching and discipleship, the people experience spiritual growth, which allowed them to spread the good news and to perform other Christian services:

4. Congregational worship and prayer: Acts 4:31 says, 'And when they had prayed, the place where they were meeting was shaken ...'. The effect of worship and prayer in the quoted Bible verse is a great occurrence that could repeat itself when believers are involved together in the same acts. This effect of God coming down in demonstration of his power is part of the benefits enjoyed when living churches were planted in locations where none was in existence.

\section{Relevance of Paul's planting patterns}

1. Focussing on large cities and towns for planting churches will have a great impact on the communities. The cities are made up of people who come from all parts of the world for business, education, trade or tourism, and thus, provide a great audience. Jesus' command to his disciples was to wait in Jerusalem for the promised Holy Spirit. Jerusalem was the city where the Holy Spirit came upon the disciples on the day of the Pentecost; the crowd which had come heard the preaching of the disciples, and through the preaching of Peter on that very same day, 
3000 souls believed in the gospel (cf. Ac 1:6-8; 2:1-41). However, the writer is not saying that the rural areas do not need churches, but cities and towns continually remain major zones of the great gathering of people from all areas. If churches are saturated in cities and towns, more people will be reached for Christ.

2. Contextualising the gospel is vital in reaching people of different communities with different backgrounds and lifestyles. David Hesselgrave holds that if the gospel is to be understood, contextualisation must be relevant to the complete authority and unadulterated message of the Bible, on the one hand, and it must be related to the cultural, linguistic and religious background of the respondent, on the other hand. Because of differences in religious, cultural and linguistic backgrounds, establishing kingdom communities must take into consideration these aspects.

3. The New Testament provides examples of churches that were held in houses. Thus, house churches are still much more relevant in our contemporary times. There are areas in the world where public worship is banned, thereby making this strategy very relevant. Christians reached China with the gospel through the use of house churches. Some New Testament references include Colossians 4:15, Romans 16:5, 1 Corinthians 16:19 and Philemon 2. There would be a great achievement by engaging house churches in the fulfilment of the Great Commission. Hence, its relevance is undisputable.

\section{Conclusion}

Church planting is like harvesting and warehousing of souls who have been saved for refining and equipping such that they also can become tools to be sent out for similar work of harvesting and warehousing for spiritual processing through the teachings of the word of God. It is a spiritual exercise or assignment put in place by Jesus for those who are his disciples and according to the intention of God through which his kingdom was established and expanded here on the earth. This assignment is strictly at God's terms for anyone who has been called into a relationship and particularly the church or assembly put together by him for his purpose. That is why the biblical principles established by the apostles and early church through the help of the Holy Spirit become the standard and guide to achieve the Great Commission. After assessing Paul and his church planting strategies and its relevance, the writer believes that Paul's church-planting strategies are feasible in modern times. Paul had a flexible mode of operation developed under the guidance of the Holy Spirit and subject to his direction and control. Paul said the Spirit led him, but he also had a reasonable idea to transport the gospel into different places where it would flourish and reach the maximum number of people. That Paul put a reasonable amount of thought and planning into his work seems evident with the fact that the Spirit led him in both creating and executing that strategy. The modern church needs both a prayerful submission to the
Holy Spirit and a rational, reasonable strategy to engage modern culture with the power of the gospel. It is important to emphasise that although new strategies have emerged, the author does not criticise other strategies that are aiding the fulfilment of the task of disciplining all nations.

However, just as not every strategy can work in every context in this modern day, not every strategy can be effectively used by every church planter. Every church planter must be able to determine the best-suited strategy per context and offer more significant opportunities for fulfilling the Great Commission.

\section{Acknowledgements}

The author wishes to express his gratitude to the Almighty God for his grace upon his life. Also, the author appreciates his wife Mrs Oluwatoyin Wumi Alawode for her undying love for him.

\section{Competing interests}

The author has declared that no competing interest exists.

\section{Author's contributions}

The author has declared that he is the sole author of this research article.

\section{Ethical consideration}

This article followed all ethical standards for a research without direct contact with human or animal subjects.

\section{Funding information}

This research did not receive any specific grant from funding agencies in the public, commercial or not-for-profit sectors.

\section{Data availability statement}

Data sharing is not applicable to this article as no new data were created or analysed in this study.

\section{Disclaimer}

The views and opinions expressed in this article are those of the author and do not necessarily reflect the official policy or position of any affiliated agency of the author.

\section{References}

Allen, R., 1962, The spontaneous expansion of the church, B. Eerdmans Publishing company, Grand Rapids, MI.

Arn, W. \& Arn, C., 1982, The master plan for making disciples, Church Growth Press, Pasadena, CA

Becker, P., Carpenter, J. \& Williams, M., 2003, The new dynamic church, Planting Handbook.

Cheyney, T., Putman, J.D. \& Sander, V. (eds.), 2003, Seven steps for planting churches, North American Mission Board, Southern Baptist Convention, Alpharetta, GA.

Elli, R. \& Mitchell, R., 1992, Radical church planting, Crossway, Cambridge.

Glasser, A.F. \& McGavran, D., 1983, Contemporary Theologies of Mission, Baker Pub Group, CA. 
Gschwend, C., 2017, The Holy Spirit as church planter, viewed 02 November 2017 from www.acts29.com/the-holy-spirit-as-church-planter.

Morgan, H., 2013, Pauline strategy for establishing churches, viewed 01 August 2018, from faithbiblechurch.com.

Murray, S., 1998, Church planting, laying foundations, Pinnacle Publishers, New York, NY.
Payne, J.D., 2016, The Great Commission and church planting, viewed 03 July 2018, from northamericanmission.org.

Ugo, I., 2012, 'St. Paul's church planting strategies as revealed in selected passages in the Book of Acts', Global Missiology English 3(9), viewed 06 November 2017, from https://ojs.globalmissiology.org/index.php/english/article/view/714/1758.

Wagner, P.C., 1990, Church planting for a greater harvest, Regal Books, Ventura, CA. 